\title{
School Play Activities: Assessment of Educators' Knowledgeability of Physical, Creative and Cognitive Development of Basic Education Children
}

\author{
Bassey E. Udoukpong Oto-Obong J. Ekpo \\ Faculty of Education, University of Uyo, UYO
}

\begin{abstract}
The purpose of the research study was to assess the educators' knowledgeability regarding children's physical, creative and cognitive development through play activities in Basic Education schools in Uyo Urban of Akwa Ibom State, Nigeria. It was assumed that the findings of the study would help educators to have an understanding that pupils' play activities should not be regarded as time for children to expend excess energy while the teachers take rest. A 5-point structured questionnaire with 30 item-statements based on the fundamental principle of Developmentally Appropriate Practice (DAP) was used to elicit opinion from the respondents. A sample of 180 educators randomly drawn from 18 Basic Education schools in Uyo Urban was surveyed. The reliability index of the instrument was 0.78 determined through Cronbach Alpha method. The data collected were analysed using frequency, percentage and the rank order statistics. The findings of the study showed that educators implementing the Basic Education programme are quite knowledgeable of children's physical, creative and cognitive development through school play activities but the highest ranking goes for the physical development. This seems to suggest that the goals of play activities are not mutually exclusive, hence, children's development should be considered wholistically through play activities.
\end{abstract}

Keywords: Play activities, knowledgeability, DAP, physical, creative and cognitive development.

DOI: $10.7176 / \mathrm{JEP} / 10-15-19$

Publication date:May $31^{\text {st }} 2019$

\section{Background of the Study}

Teachers' task in working with young children is to provide an environment in which children's enthusiasm is nurtured rather than subdued or even destroyed. This is why schools will continue to emphasize the importance of engaging in Developmentally Appropriate Practice - a concept of matching practice with what we know about the development of young children (Essa, 2011). Young children are eager to learn. This is an awesome responsibility on the shoulders of the Basic Education educators that can be met through careful and sensitive study and understanding of the characteristics and needs of young children.

All children and young people need to play. The impulse to play is innate. Play is a biological, psychological and social necessity, and is fundamental to the healthy development and wellbeing of individuals and communities (Power, 2000). Play is a process that is freely chosen, personally directed and intrinsically motivated. Play is simply about having fun! (Ginsburg, 2007). According to Friedrich Froebel (1782-1852); "Play is the highest phase of child development" (Essa, 2011:129).

One of the commonest things among all children is the need to play which serves as a means of learning about and making sense of the world. But more than that, play is essential to all aspects of children's development. Arnold Gesell (1880-1961) cited in Essa (2011) underscores that, "play is an important vehicle for developing self-regulation as well as for promoting language, cognition and social competence" (page 43). Play promotes mastery as children practice skills; it furthers cognitive development as thinking abilities are stretched; it involves language, encouraging new uses; it involves physical activity; it helps children work through emotions; its inventive nature makes it creative and it is often a socializing agent (Steglin, 2005). Play is the way children come to understand the world.

The importance of play in Basic Education programme is also acknowledged in Nigeria's National Policy on Education as it states that Early Childhood Care, Development and Education shall among its purposes be "to inculcate in the child the spirit of enquiry and creativity through the exploration of nature, the environment, art, music and the use of toys; develop a sense of cooperation and team spirit; and teach the rudiments of numbers, letters, colours, shapes among others through play" (FRN, 2013:5; Section 15e, f and h).

Government plans to achieve the objective of Basic Education by ensuring that the curriculum of teacher education is oriented towards play-way method as well as make provision in teacher education programme for specialization and for retraining of teachers (FRN, 2013:8; Section $16 \mathrm{~d}$ and e). It is important for teachers to be aware of the different types of play and to recognise that children develop increasing physical, social, creative and cognitive skills as they progress.

A wealth of research supports the value of play (Steglin, 2005). Without the opportunities for play and an environment that supports it, children's learning is limited. Early childhood programmes that provides time for 
play that promotes and supports learning increase and enhance children's opportunities for success in school and life (Morrison, 2001).

All in all, the foregoing observations show the importance of play as a human development building block. But without an empirical assessment of educators' knowledge regarding the developmental goals of play activities in Basic Education, there exists little basis for improving play facilities in schools. Teachers would have great reluctance to change the status quo of their perception of play in educational system without adequate proof of need. It was against the background of helping educators understand the developmental roles of play activities in Basic Education that this study identified educators' knowledge of goals of play activities as the area of concern for examination.

\section{Play Activities and Children's Physical Development}

Traditionally, physical development has been considered from maturational theory perspective. This view point is based on information about when children reach development milestones in such functions as sitting, standing, and walking, tasks that are largely determined by the maturation of the nervous system (Shonkoff and Phillips, 2000). But in more recent years, Piaget's theory has led to the perpetual motor model of physical development, a more integrative view proposing that motor behaviours are a prerequisite for and lead to cognitive abilities (Williams and Monsma, 2006). Because young children learn through physical movement and interaction with the environment, they must be provided with numerous movement opportunities and experiences. Furthermore, this viewpoint also assumes that a child's academic performance can be improved by increasing the amount of motor activity, because cognition is predicated on motor experience (Williams and Abernathy, 2007). In fact, Developmentally Appropriate Practice indicates that children must have opportunities throughout the day to move about freely, use their large muscles and engage in vigorous movement (Copple and Bredekamp, 2009).

Young children need to develop physical capabilities through many play experiences in which they can explore their outside world. Play, games, and sports have characteristics that are tied to developmental readiness and appropriateness. The challenge to Basic Education educators is to develop appropriate gross motor and physical fitness activities.

Physical activity in childhood is important for many reasons and a variety of sources indicate a direct relationship between physical activity and children's health (Hope, 2007). In early childhood physical exercise helps build strong bones, muscle strength, and lung capacity (Lindon, 2007). It may also increase cognitive, improve academic achievement and accelerate neuro-cognitive processing.

Play contributes to children's fine and gross motor development and body awareness as they actively use their bodies. Learning to use a writing tool, such as a marker, is an example of fine motor development through play. Playing with writing tools helps children refine their fine motor skills. Gross motor development such as hopping, and skipping, develops also in natural progression. Thus, using their bodies during play enables children to feel physically confident, secure and self-assured (Isenberg and Jalongo, 2010).

Playful children are happier, better adjusted, more cooperative, and more popular with their peers than those who play less. According to Singer (1994), "Children play longer when a wide variety of toys is available. Playful children are more physically active, creative, humorous, imaginative, emotionally expressive, curious and communicative" (page 132). Play in early childhood allows children to give voice to their experiences and to have a safe place to express confusing and painful feelings, and to find ways of overcoming emotional traumas.

\section{Play Activities and Children's Creative Development}

Creativity has been defined in a number of ways. Most definitions include such concepts as originality, imagination, divergent thinking and the ability to create something new or to combine things in novel but meaningful ways. "The goal of engaging in creative arts is to communicate, think and feel" (Drew and Rankin, 2004). One trait often associated with creative thinking is fluency, the ability to generate many relevant ideas on a given topic in a limited time. Another measure of creativity is flexibility, the capability of adapting readily to change in a creative productive manner. Creative people have heightened awareness of their perceptions, feelings and images. They often experience through their senses what others miss (Essa, 2011).

The Basic Education programme should provide an environment in which these concepts are encouraged and valued. Creativity has to be nurtured. It does not happen on its own. The teacher plays an important role in fostering creativity by providing a variety of materials and encouraging imaginative use of them. Children need to have ample time block during the day in which they can explore and try out their ideas (Drew and Rankin, 2004).

The physical setting can support creativity through the provision of and access to, a wide range of open-ended materials, ones that lend themselves to various uses. Whenever children are confronted with material that has multiple uses, they have to make choices about how to use the material and have to use imagination because it does not dictate a single outcome. Well-stocked early childhood programme should be full of open-ended materials. Examples include a wide variety of art materials, manipulatives, blocks, senory materials, puppets, dramatic play props, musical instruments, and versatile outdoor equipment. Classroom areas should be set up so that traffic flow 
does not interfere or disrupt ongoing activity (Essa, 2011). Creativity is, in fact a part of cognitive development. As children explore and manipulate things, they try out new combinations of the things they already know about. Each classroom should incorporate an art centre with a range of materials for exploration, and creative construction (Gandini, 2005).

Play provides an arena for creative activities and processes (Saracho, 2002). Some observations of creative adults uncovered that their work processes stem from some aspects of child's play (Root - Bernstein and Root Bernstein, 2006). A number of studies have demonstrated the mechanism that pretend play facilitates creativity through cognitive and affective processes in children (Taylor and Sutton, 2002; Moore and Russ, 2008). The major findings of their work lend support to empirical links between play and divergent thinking. The play context is ideal for supporting children's creative and imaginative thought because it offers a risk-free environment. Research supports the notion that play and creative thought are related behaviours because they both rely on children's ability to use symbols (Isenberg and Jalongo, 2010).

\section{Play Activities and Children's Cognitive Development}

Piaget (1896-1980) offers a view of cognitive development that is based on allowing children to build concept actively rather than on providing those concepts through direct teaching. According to Piaget's cognitive developmental theory, one function of the mind is to categorize information into schemata. This is an active process by which the young child continually finds relationship among objects (Goldhaber, 2000).

By physically manipulating and changing objects, the child constructs knowledge about the objects and their relationships. Knowledge is not something that is "poured" into children by some external source, such as the teacher, but something that the children have to construct for themselves. This is why Piaget's theory is also called, a constructivist theory (Essa, 2011).

Children's cognitive development is best promoted when they are in a safe, loving environment where their basic needs are met. Furthermore, such environment must be rich in appropriate stimuli and sensory experiences that help them to explore and learn about their world. Children need a variety of materials that can be explored, combined in different ways, put together and taken apart, and in many other ways that allow for experimentation. In addition, games and toys that help children recognise what causes things to happen and that identify them as the causal agent should be provided (Gestwicki, 2009).

"Play is our need to adapt the world to ourselves and create new learning experiences" (Elkind, 2007:3). Piaget and Vygotsky, two of the most influential 20th century theorists of cognitive development, both emphasized the essential role of play in children's development. According to Piaget, play provides children with extensive opportunities to interact with materials in the environment and construct their own knowledge of the world, making play one of the most important elements in cognitive development (Zigler, 2009). Lester and Russell (2008) argue that the main contribution of play to learning is to help children understand the link between motivation, emotion and reward, allowing them to coordinate their feelings, thoughts and behaviour to learning. Through play activities children learn vocabulary, concepts, problem solving, self-confidence, motivation and an awareness of the needs of others (Zigler, 2009).

Constructive and imaginative plays have been identified as the most important for cognitive development (Health Council of the Netherlands, 2004). Allowing a child time and freedom to complete self-directed play activities to their own satisfaction supports the child's ability to concentrate (Elkind, 2007). Play reduces the tension that often comes with having to achieve or needing to learn and in play adults do not interfere and children relax. In school settings, play helps children adjust to new environment as well as giving them basis for extending their learning (Ginsburg, 2007).

Basic Education educators should know which types of play materials are most appropriate for children at different ages. They should know how to arrange play rooms in order to encourage developmentally appropriate symbolic play. Educators should also be aware that different contexts of play are needed to encourage the development of children's representation, social interaction and communication skills.

\section{Statement of the Problem}

Many problems tend to beset the realization of the goals despite the significance of play activities in the developmental domains of children. This is partly due to the non-availability of play materials in schools and partly due to teachers' perception of play activities. Some teachers perceive play as a trivial pursuit. Recess, creative activities and physical education have been decreased or eliminated for many children as schools face the pressures of meeting children's academic requirements in respect of literacy, numeracy and the ability to communicate effectively. In addition, many parents put pressure on their children at early ages to prepare for the future by spending more time on academic and less on free play (Morrison, 2001).

Teachers of young children often neglect gross motor development instead emphasize fine motor, cognitive and social areas in the curriculum. Unlimited gross motor activity is most likely to occur during outdoor play. The outdoor area and the time children spend outdoors should be integral parts of Basic Education programme 
because of their many inherent values. Outdoor play is not just a time for children to expend excess energy while teachers take break. Well-planned outdoor activities can meet a range of developmental and educational objectives (Essa, 2011). But without empirical studies to find out educators' knowledge of play activities as human development building goals, the educational process of improving children's developmental domains - the physical, creative and cognitive through play may be misdirected or incomplete. Hence, the need to examine educators' knowledge of goals of play activities in the Basic Education schools in Uyo Urban of Akwa Ibom State.

\section{Purpose of the Study}

The study specifically aimed at the following objectives:

1. To determine how knowledgeable the Basic Education educators are in children's physical development by school play activities.

2. To examine how knowledgeable the Basic Education educators are in children's creative development by school play activities.

3. To assess how knowledgeable the Basic Education educators are in children's cognitive development by school play activities.

\section{Research Questions}

The following research questions guided the study.

1. How knowledgeable are the Basic Education educators in children's physical development by school play activities?

2. How knowledgeable are the Basic Education educators in children's creative development by school play activities?

3. What is the Basic Education educators knowledge regarding children's cognitive development by school play activities?

\section{Methods}

The descriptive research was used for the study. In the descriptive research which is a form of non-experimental study, questionnaire was used to collect information and the goal was to understand the opinion of teachers about the goals of play activities in Basic Education programme. Since the study sought to find out pre-primary and primary school educators' knowledge of physical, creative and cognitive development goals of play activities, the descriptive research approach was deemed suitable. This is supported by the fact that the researchers followed the three steps recommended for the conduct of descriptive research: (1) randomly selection of a sample from a defined population, (2) determining of sample characteristics, and (3) inference of the characteristics of the population based on the sample (Johnson and Christenson, 2004).

The population of the study consisted of all the 685 teachers in all the 18 pre-primary/ primary public and private school sector of the Basic Education programme in Uyo Urban of Akwa Ibom State during the 2016/17 academic session. A total of 180 pre-primary/primary school teachers (educators), with a minimum qualification of the Nigeria Certificate in Education diploma and members of the Teachers' Registration Council of Nigeria constituted the sample for the study. The respondents were randomly drawn from all the 18 schools on the basis of ten participants from each school.

A structured questionnaire with a 30-item statements based on the fundamental principle of Developmentally Appropriate Practice (DAP) adapted from Essa (2011) was employed to collect the data for the study. Each of the examined developmental domain - physical, creative and cognitive - had ten item-statements with a-five response options (Strongly Agree, Agree, Undecided, Disagree and Strongly Disagree).

Content suitability and validity were established by the panel of experts consisting of University Faculty members, school administrators and school head-teachers. The internal consistency reliability coefficient was established using teachers not included in the main study. The reliability coefficient of the instrument determined through Cronbach Alpha method was 0.78 .

Personal visits were made by the researchers to administer the questionnaire to the participants in the schools through the permission of the school head-teachers. All the selected teachers responded to the research instrument. Data were analysed using frequency, percentage and rank order.

\section{Results}

In order to answer the research questions, participants' responses to the 5-point ranking scale statements were regrouped into three: "Agree", "Undecided" and "Disagree" columns while frequency, percentage and rank order statistics were used to analyze the data in tables.

Research Question 1: How knowledgeable are the Basic Education educators in children's physical development by school play activities?

Frequency, percentage and rank order statistics were employed to analyze the data as presented in Table 1. 
Table 1: $\quad$ Frequency, percentage and rank order of educators' responses to statements concerning children's physical development by school play activities $(\mathrm{N}=180)$.

\begin{tabular}{|c|c|c|c|c|c|c|c|c|}
\hline \multirow[t]{2}{*}{ Items } & \multirow[t]{2}{*}{ Statements } & \multicolumn{2}{|c|}{ Agree } & \multicolumn{2}{|c|}{ Undecided } & \multicolumn{2}{|c|}{ Disagree } & \multirow{2}{*}{$\begin{array}{l}\text { Rank } \\
\text { Order }\end{array}$} \\
\hline & & f & $\%$ & f & $\%$ & $\mathbf{f}$ & $\%$ & \\
\hline 1. & $\begin{array}{l}\text { Running, crawling, climbing and throwing activities } \\
\text { do contribute to children's physical development. }\end{array}$ & 80 & 100 & 0 & 0.00 & 0 & 0.00 & 1 \\
\hline
\end{tabular}

2. Pupils in Basic Education schools need more play than games.

$\begin{array}{lllllll}158 & 87.77 & 21 & 11.67 & 1 & 0.55 & 4 \\ 177 & 98.33 & 3 & 1.67 & 0 & 0.00 & 2 \\ 165 & 91.67 & 6 & 3.33 & 9 & 5.00 & 3\end{array}$
to use their muscles and engage in vigorous movement.

5. Classrooms should provide enough space to engage pupils in movement activities.

$\begin{array}{lllllll}156 & 85.67 & 18 & 10.00 & 6 & 3.33 & 5\end{array}$

6. Items such as hoops, jump ropes and balls encourage bodily movement.

$\begin{array}{lllllll}90 & 50.00 & 30 & 16.67 & 60 & 33.33 & 8\end{array}$

7. Basic education teachers need to be more concerned with providing pupils' physical fitness as part of the daily school programme.

$\begin{array}{lllllll}60 & 33.33 & 15 & 8.35 & 105 & 58.33 & 10\end{array}$

8. Outdoor play is not just a time for pupils to expend excess energy while teachers take a break.

$\begin{array}{lllllll}86 & 47.77 & 24 & 13.33 & 70 & 38.88 & 9\end{array}$

9. Well-planned outdoor activities can meet a range of developmental and educational objectives.

$\begin{array}{lllllll}135 & 75.00 & 18 & 10.00 & 27 & 15.00 & 7\end{array}$

10. It is important for pupils to have many opportunities to learn and practice basic physical skills.

$\begin{array}{lllllll}144 & 80.00 & 18 & 10.00 & 18 & 10.00 & 6\end{array}$

\section{Average \% responses \\ $\mathbf{7 5 . 0 5} \quad 8.50$ \\ 16.44}

The responses to the statements concerning play activities vis-à-vis children's physical development as shown in Table 1 indicate that the participants "agreed" on seven out of ten statements with the responses on and above the average percentage of 75.05. The "agreed" statements in ranked order were item $1(100.00 \%)$, item $3(98.33 \%)$, item $4(91.67 \%)$, item $2(87.77 \%)$, item $5(86.67 \%)$, item $10(80.00 \%)$ and item $9(75.00 \%)$ respectively. Responses to items 6,7 and 8 fell short of meeting the average percentage of "agree" response of 75.05 respectively. Item 7 with 33.33\% "agree" response was the least positively endorsed statement. The overall average percentage responses to the questionnaire statements on educators' knowledge regarding children's physical development through play activities were $75.05 \%$ for "agree", $8.50 \%$ for "undecided" and $16.44 \%$ for "disagree" respectively. 
Research Question 2: How knowledgeable are the Basic Education educators in children's development by school play activities?

Frequency, percentage and rank order statistics were used to analyze the data as shown in Table 2.

Table 2: Frequency, percentage, and rank order of educators' responses to statements concerning children's creative development by school play activities $(\mathrm{N}=180)$.

\begin{tabular}{|c|c|c|c|c|c|c|c|c|}
\hline \multirow[t]{2}{*}{ Items } & \multirow[t]{2}{*}{ Statements } & \multicolumn{2}{|c|}{ Agree } & \multicolumn{2}{|c|}{ Undecided } & \multicolumn{2}{|c|}{ Disagree } & \multirow{2}{*}{$\begin{array}{l}\text { Rank } \\
\text { Order }\end{array}$} \\
\hline & & $\mathbf{f}$ & $\%$ & f & $\%$ & f & $\%$ & \\
\hline 1. & $\begin{array}{l}\text { Play materials which can lend themselves to various } \\
\text { uses help in children's creativity development. }\end{array}$ & 159 & 88.33 & 15 & 8.33 & 6 & 3.33 & 2 \\
\hline 2. & $\begin{array}{l}\text { A variety of art materials, blocks, puppets, musical } \\
\text { instruments and multipurpose outdoor equipment can } \\
\text { support creativity among children. }\end{array}$ & 147 & 81.67 & 27 & 15.00 & 6 & 3.33 & 6 \\
\hline 3. & $\begin{array}{l}\text { Books calling for colouring "within the lines" hinder } \\
\text { creative expression of school children. }\end{array}$ & 81 & 45.00 & 27 & 15.00 & 72 & 40.00 & 9 \\
\hline 4. & $\begin{array}{l}\text { Where children have free access to materials such as } \\
\text { crayons, marking pens, pencils, and chalk, such } \\
\text { become the favourite materials for drawing. }\end{array}$ & 159 & 88.33 & 18 & 10.00 & 3 & 1.67 & 2 \\
\hline 5. & $\begin{array}{l}\text { Music should be taken as part of nursery school } \\
\text { children's everyday play and exploration. }\end{array}$ & 150 & 83.33 & 21 & 11.67 & 9 & 5.00 & 5 \\
\hline 6. & $\begin{array}{l}\text { Cognitive, social, and physical development of young } \\
\text { school children can be fostered through play } \\
\text { activities. }\end{array}$ & 163 & 90.55 & 10 & 5.55 & 7 & 3.88 & 1 \\
\hline 7. & $\begin{array}{l}\text { Teaching new songs to children is probably the most } \\
\text { common music activity in early childhood education. }\end{array}$ & 14 & 7.77 & 19 & 10.55 & 147 & 81.66 & 10 \\
\hline 8. & $\begin{array}{l}\text { Asking children to move as the music makes them } \\
\text { feel can result in a variety of creative dance. }\end{array}$ & 125 & 69.44 & 10 & 5.55 & 45 & 25.00 & 8 \\
\hline 9. & $\begin{array}{l}\text { Children putting together what they know in new } \\
\text { ways express their development of creativity. }\end{array}$ & 155 & 86.11 & 23 & 12.77 & 2 & 1.11 & 4 \\
\hline 10. & Drawing and musical equipment foster creativity. & 130 & 72.22 & 28 & 21.11 & 12 & 6.66 & 7 \\
\hline
\end{tabular}

\section{Average \% responses}

71.28

11.55

17.16

Educators' responses to the statements regarding play activities vis-à-vis children's creative development as presented in Table 2 show that the respondents "agreed" on seven out of the ten item statements with the responses above the average percentage of 71.28\%. The "agreed" statements in ranked order were item $6(90.55 \%)$, items 1 and $4(88.33 \%)$ respectively; item $9(86.11 \%)$, item $5(83.33 \%)$, item $2(81.67 \%)$, and item $10(72.22 \%)$.

Responses to items 3,7, and 8 statements fell short of meeting the average percentage of "agree" benchmark of 71.28 respectively. Item 7 with $7.77 \%$ "agree" response was the least positively accepted statement. The overall average percentage responses to the questionnaire statements on educators' knowledge regarding children's creative development through school play activities were $71.28 \%$ for "agree", $11.55 \%$ for "undecided", and $17.16 \%$ for "disagree" respectively.

Research Question 3: What is the Basic Education educators' knowledge regarding children's cognitive development by school play activities?

Frequency, percentage and rank order statistics were employed to analyze the data in respect of the above research question as presented in Table 3 
Table 3: Frequency, percentage and rank order of educators' responses to statements concerning children's cognitive development by school play activities $(\mathrm{N}=180)$.

\begin{tabular}{|c|c|c|c|c|c|c|c|c|}
\hline \multirow[t]{2}{*}{ Items } & \multirow[t]{2}{*}{ Statements } & \multicolumn{2}{|c|}{ Agree } & \multicolumn{2}{|c|}{ Undecided } & \multicolumn{2}{|c|}{ Disagree } & \multirow{2}{*}{$\begin{array}{l}\text { Rank } \\
\text { Order }\end{array}$} \\
\hline & & & $\%$ & f & & f & $\%$ & \\
\hline 1. & $\begin{array}{l}\text { Items that can be compared, grouped, counted, matched } \\
\text { or placed in logical order encourage and enhance } \\
\text { mathematics concepts. }\end{array}$ & 159 & 88.33 & 15 & 8.33 & 6 & 3.33 & 3 \\
\hline 2. & $\begin{array}{l}\text { Children playing to throw the ball hard so as to make it } \\
\text { go further (force) and rolling objects faster down a steep } \\
\text { incline (gravity) are acquiring the scientific vocabulary of } \\
\text { physics. }\end{array}$ & 135 & 75.00 & 33 & 18.33 & 12 & 6.67 & 9 \\
\hline 3. & $\begin{array}{l}\text { When children observe that soap and water result in } \\
\text { bubbles, water added to sand makes sand moldable while } \\
\text { sugar or salt becomes invisible when stirred into water, } \\
\text { they are dealing with the scientific vocabulary of } \\
\text { chemistry. }\end{array}$ & 103 & 57.22 & 75 & 41.66 & 2 & 1.11 & 10 \\
\hline 4. & $\begin{array}{l}\text { Excellent books provide a wealth of ways to develop } \\
\text { children's language experience. }\end{array}$ & 150 & 83.33 & 20 & 11.11 & 10 & 5.55 & 4 \\
\hline 5. & $\begin{array}{l}\text { A school should have a good selection of children's } \\
\text { books in its library to be rotated as curriculum topics and } \\
\text { children's interest change. }\end{array}$ & 162 & 90.00 & 12 & 6.66 & 6 & 3.33 & 2 \\
\hline 6. & $\begin{array}{l}\text { The use of puppets as actors is another way to present } \\
\text { stories for children. }\end{array}$ & 138 & 76.66 & 40 & 22.22 & 2 & 1.11 & 7 \\
\hline 7. & $\begin{array}{l}\text { Charts, lists, labels and notice boards that surround } \\
\text { children in the classroom contribute to print awareness } \\
\text { and literacy development. }\end{array}$ & 141 & 78.33 & 36 & 20.00 & 3 & 1.67 & 6 \\
\hline 8. & $\begin{array}{l}\text { Books with simple pictures and few words are suitable } \\
\text { for supporting language literacy development in nursery } \\
\text { class. }\end{array}$ & 144 & 80.00 & 33 & 18.33 & 3 & 1.67 & 5 \\
\hline 9. & $\begin{array}{l}\text { Children enjoy interacting with books, seeing bright } \\
\text { visual pictures, hearing the repetition of familiar words } \\
\text { and savouring pleasuring rhythmic sound. }\end{array}$ & 177 & 98.33 & 3 & 1.66 & 0 & 0.00 & 1 \\
\hline 10. & $\begin{array}{l}\text { Children love simple stories and rhymes about familiar } \\
\text { events, routines, experiences and feelings. }\end{array}$ & 138 & 76.66 & 38 & 21.11 & 4 & 2.22 & 7 \\
\hline & Average $\%$ responses & & 70.38 & & 16.91 & & 2.66 & \\
\hline
\end{tabular}

The responses to the statements regarding play activities vis-à-vis children's cognitive development as shown in Table 3 indicate that the educators "agreed" on nine out of the ten statements with the responses above the average percentage of 70.38. The "agreed" statements in ranked order of the highest to the baseline average are: item $9(98.33 \%)$, item $5(90.00 \%)$, item $1(88.33 \%)$, item $4(83.33 \%)$, item $8(80.00 \%)$, item $7(78.33 \%)$, items 6 and $10(76.66 \%)$ respectively and item $2(75.00 \%)$.

Responses to item 3 did not meet the average percentage of "agreed" response of 70.38 . The overall average percentage responses to the questionnaire statements on educators' knowledge regarding children's cognitive development through school play activities were: $70.38 \%$ for "agree", $16.91 \%$ for "undecided" and $2.66 \%$ for "disagree" respectively.

\section{Discussion of Findings}

Basic Education Educators' Knowledge of Children's Physical Development by School Play Activities

The respondents' answers to the Research Question 1 indicated that Basic Education educators are knowledgeable about children's physical development by school play activities. This is predicated on the fact that the participants in this research study "agreed" on 7 out of the 10 school play activity statements raised about children's physical development. Only three items failed to meet the "agree" level of acceptance.

This finding is supported by Dodge (2004) who asserted that the school physical environment enhances both fine and gross motor development through a range of appropriately challenging equipment and materials. Schools involved in this study have materials and equipment of different types for children's outdoor and indoor activities - plays, games and sports. Hope (2007) opines that physical activity in children is important for many reasons and 
a variety of sources indicate a direct relationship between physical activity and children's health (Hope, 2007). The overwhelming agreement in responses to the statements on children's physical development suggests that the respondents are aware of the fact that school play activities go beyond relaxation, pleasure and recreation. Therefore, the provision of block time in school for children's play activities should be seen as having latent benefit of physical development. Using their bodies during play enables children to feel physically confident, secure and self-assured. Thus, early childhood, physical exercise helps to build strong bones, muscles strength and lung capacity (Lindon, 2007).

The low respondents' rating of statement 6 , on children's physical development could be explained to that wording of that statement. Statement 6 did not specify physical action whereby physical development of children could be linked to such action(s). The rhetoric nature of the item might have confused the respondents thereby resulting in low respondents' agreement on its contribution to children's physical development. The low respondents' positive endorsement of items 7 and 8 could be accounted for by the educators' factor and their perception of play. Most Basic Education educators believe that the basic function of the school is to meet children's academic requirements in respect of literacy, numeracy and the ability to communicate effectively. Some parents and teachers perceive play as trivial pursuit. Hence, educators with such mentality are bound to downgrade the school play activities against their positive roles in children's physical development. Educators who cannot link school play activities with children's physical development tend to be deficient in their knowledge of educational psychology and children.

\section{Basic Education Educators' Knowledge of Children's Creative Development by School Play Activities}

The participants' responses to the Research Question 2 revealed that Basic Education educators are knowledgeable about children's creative development by school play activities. The premise for this assertion is their response to the questionnaire instrument whereby they "agreed" on seven out of the ten play activity statements raised regarding children's creative development. The finding for the Research Question 2 is supported by Saracho (2002) and Isengerg and Jalongo (2010). Saracho opines that play provides an arena for creative activities and processes while Isenberg and Jalongo lend credence to it that research supports the notion that play and creative thought are related behaviours because they both rely on children's ability to use symbols. The teacher should play an important role in fostering creativity by providing a variety of materials and encouraging imaginative use of them.

Further explanation to the educators' high positive responses of "agree" to the creative development school play activity statements could be attributed to the National Policy on Education objectives set for the Basic Education programme which among others is, "to inculcate in the child the spirit of enquiry and creativity ... art, music and the use of toys through play" (FRN, 2013:6). Hence, the finding to the Research Question 2 is an indication of educators' sensitivity to children's creative needs in keeping with the national policy on education demand.

The low rating of items 3, 7 and 8 on children's creative development by school play activities could be a factor of the respondents' limited knowledge of educational psychology and children as well as the overemphasis of the academic requirements of the "manifest" school curriculum over the "hidden" curriculum functions of the school.

The poor positive response to item 3 specifically reveals the respondents' limited knowledge of graphic arts in terms of drawing, painting, and printmaking. This assumption is predicated on the work of Essa (2011) which states that, "Early childhood educators advise against providing children with dittoes or colouring books because they inhibit creative expression, are not developmentally appropriate because "colouring within the lines" require fine motor control beyond the abilities of many young children" (p.267). The acceptable response to the Statement 3 should be in affirmative as shown in Essa (2011) explanation, otherwise the end-product of children's activity may convey the message that their art is inadequate.

\section{Basic Education Educators' Knowledge of Children's Cognitive Development by School Play Activities}

The findings to the Research Question 3 revealed that the Basic Education educators have a satisfactory understanding of the role of school play activities in the promotion of school children's cognitive development. This is informed by the responses of the respondents to the questionnaire statements whereby they "agreed" on nine out of the ten item statements formulated to assess the educators' views on children's cognitive development vis-à-vis school play activities.

This finding is supported by Piaget's theory which has it that one function of the mind is to categorize information into schemata. By physically manipulating and changing objects, the child constructs knowledge about the objects and their relationships (Goldhaber, 2000). Furthermore, to Piaget, play activities provide children with extensive opportunities to interact with materials in the environment and construct their own knowledge of the world, thus making play one of the most important elements in cognitive development (Zigler, 2009).

The respondents' overwhelming "agree" posture on nine out of the ten-item activity statements could be accounted for as a factor of the professional training the Basic Education educators had in the theory and practice 
of education. In terms of theory, Piaget's constructivism offers a view of cognitive development that is based on allowing children to build concepts actively rather than on providing those concepts through direct teaching. Hence, it could be concluded that educators' knowledge of Piaget's theory has given them the way to understand how children think, and describing how their thinking develops. For example, because of children's need to manipulate and transform materials in the environment, learning has to be an active, not a passive, process (Essa, 2011). The objectives set by the National Policy on Education might have also guided the participants' all-out-positive responses to the questionnaire statements ranging from $75.00 \%$ to $98.33 \%$ above the average percentage response to the least being 57.22\%. Teachers are expected, among other Basic Education objectives, "To teach the rudiments of numbers, letters, colours, shapes, forms among others through play" (FRN, 2013 p.7). This requirement is supported by Zigler (2009) who asserted that through play children learn vocabulary, concepts, problem solving, self-confidence, motivation and an awareness of the needs of others.

The low ranking of Statement 3 on children's cognitive development through school play activities could be a factor of the respondents' lack of scientific vocabulary of the physical sciences. Statement 3 was to test the respondents' science concepts in the Basic Education curriculum, specifically, that of chemistry. According to Essa (2011), "Children are in constant contact with, and take in information about, the inanimate, physical elements of their world, and they acquire many scientific concepts" (page 347). But sadly, not all the educators employed in the Basic Education schools studied science disciplines prior to their becoming teachers. Hence, the respondents' limited background on scientific concepts could be adduced as the contributing factor to the low ranking of Statement 3. In sum, it could be assumed that the finding to the Research Question 3 indicates the educators' sensitivity to children's cognitive needs as required in the national policy on education in addition to their knowledgeability of the role of play in the cognitive development of children.

\section{Conclusion and Recommendations}

The rank order of the three developmental domains by average percentage responses showed that educators' knowledge of the goals of play activities in Basic Education schools reflected strongest in the physical development (75.05\%) followed by the creative development (71.28) while the cognitive development came third with $(70.38 \%)$ "agree" responses. These findings tend to suggest that educators still perceive motor development of children as the main goal of their play activities, though not mutually exclusive. Hence, children's development should be considered wholistically through play activities. Educators' responsibility in working with pupils should be to provide an environment in which children's potentialities are nurtured and sustained rather than subdued or even ignored. This informs the reason that the school should continue to emphasize the importance of engaging in developmentally appropriate practice. This responsibility can be met through careful and sensitive study and understanding of the characteristics and needs of young children.

In the light of the findings made in this study, the following recommendations are made for the betterment of children's development through play activities.

1. A large time block each day should be reserved for activities from which the children can select. Such time block should allow ample opportunity to survey the options, select an activity, get involved in it, and bring it to a satisfactory conclusion.

2. Educators should supervise play activities and participate in children's school play.

3. Children should be observed at play. Educators should learn how children play and use the learning outcome of play in planning classroom activities.

4. Educators should question children about their play, discuss what they did during play and explain to them what they have learned through play activities.

5. Play activities should be formally implemented in the Basic Education schools in order to move the school curriculum beyond literacy and numeracy levels which are all about the academic curriculum.

6. Play should be made an instructional strategy in the course of teaching - learning processes especially at the Basic Education level because of its numerous benefits to children.

\section{References}

Copple, C. E. and Bredekamp, S. (Eds.) (2009). Developmentally appropriate practice in early childhood programmes: Serving children from birth through age 8. Washington, DC: National Association for the Education of Young Children.

Dodge, D. T. (2004). The creative curriculum for preschool. New York: Thompson Delmar Learning.

Drew, W. F. and Rankin, B. (2004). Promoting creativity for life using open-ended materials. Young Children, 59(4): 38-45.

Elkind, D. (2007). The power of play: How spontaneous, imaginative activities lead to happier, healthier children. Cambridge, MA: Da Capo Press.

Essa, E. L. (2011). Introduction to early childhood education (6th ed.). Belmont, CA: Wadsworth Cengage 
Learning.

Federal Republic of Nigeria (2013). National policy on education (6th ed.). Lagos: NERDC Press.

Gandini, L. (2005). From the beginning of the atelier to materials as Language. New York: Teachers College Press, Columbia University.

Gestwicki, C. (2009). Home, school and community relations: A guide to working with parents. Belmont, CA: Wadsworth, Cengage Learning.

Ginsburg, K. (2007). The importance of play in promoting healthy child development and maintaining strong parent-child bonds. Pediatrics, 119:189-191.

Goldhaber, D. E. (2000). Theories, of human development: Integrative perspectives. Mountain View, CA: Mayfield.

Health Council of Netherlands (2004). Nature and health: The influence of nature on social, psychological and physical well-being. http:/www.forhealth.fi/pmwiki/docs/dutch-health-council-review. Pdf. (Accessed December, 2010).

Hope, G. (2007). Wild woods or urban jungle: Playing it safe or freedom to roam. Education, 3-13, 4, 321-32.

Isenberg, P. and Jalongo, M. (2010). Creative expression and play in the early childhood curriculum. Englewood Cliffs, NJ: Prentice-Hall.

Johnson, B. and Christensen, L. (2004). Educational Research: Qualitative, Quantitative and Mixed Approaches. New York: Pearson Education, Inc.

Lester, S. and Russell, W. (2008). Play for a change: Play, policy and practice. London: Play England.

Lindon, J. (2007). Understanding children and young people: Development from 5 to 18 years. London: Hodder Arnold.

Moore, M. and Russ, S. W. (2008). Follow-up of pretend play intervention: Effects on play, creativity and emotional processes in children. Creativity Research Journal, 2:427-436.

Morrison, G. S. (2001). Early childhood education today (8th ed.). upper Saddle River, NJ: Merrill Prentice Hall.

Power, T. (2000). Play and exploration in children and animals. London: Lawrence Eribaum Associates.

Root-Bernstein, M. and Root-Bernstein, R. (2006). Imaginary world play in childhood and maturity: Its impact on adult creativity. Creativity Research Journal, 18:405-425.

Saracho, O. N. (2002). Young children's creativity and pretend play. Early Childhood Development and Care, 172:431-438.

Shonkoff, J. P. and Phillips, D. A. (2000). From neurons to neighbourhoods: The science of early childhood development. Washington, DC: National Academic Press.

Singer, J. (1994). Imaginative play and adaptive development. In J. Goldstein (ed.). Toys, play and child development. Cambridge University Press.

Steglin, D. A. (2005). Making the case for play policy: Researched-based reason to support play-based environment. Young Children, 60(2): 76-85.

Taylor, I. A. and Sutton, A. B. (2002). Developing creativity in gifted young adults. Education, 94:266-268.

Williams, H. G. and Abernathy, D. (2007). Assessment of gross motor development. In B. A. Bracken and R. J. Nagle (Eds.). The psychoeducational assessment of preschool children (pp.204-233). Mahwah, NJ: Lawrence Eribaum Associates.

William, H. G. and Monsma, E. V. (2006). Assessment of fine motor development. In B. A. Bracken and R. J. Nagle (Eds.) the psychoeducational assessment of preschool children (pp. 397-434). Mahwah, NJ: Lawrence Eribaum Associates.

Zigler, E. (2009). Play under siege: A historical perspective. Zero to Three, 30(1): 4-11.

\section{Acknowledgements}

Our uncountable thanks go to the headteachers and the teachers in the Basic Education Schools where the research samples were drawn. We gratefully acknowledge their cooperation in providing responses to our research instrument, for without them the data for the analysis would not have been possible.

We also thank the authors and researchers whose works have been cited in our study hence, acknowledged in the Reference list. Their insightful write-ups were basic for the literature of this study and fundamental to the discussion of our research findings. 